\title{
Growth hormone treatment in growth-retarded adolescents after renal transplant
}

\author{
A C S Hokken-Koelega, T Stijnen, MA J de Ridder, S M P F de Muinck Keizer-Schrama, E D Wolff, M C JW de Jong, \\ R A Donckerwolcke, J W Groothoff, W F Blum, S L S Drop
}

\section{Summary}

Growth failure is a psychosocial problem for many patients who have undergone renal transplantation.

18 adolescents (mean age 156 , range $11.3-195$ ) with severe growth retardation after renal transplantation were treated with biosynthetic growth hormone $(\mathrm{GH})$ for 2 years. All received prednisone, administered daily or on alternate days, with azathioprine and/or cyclosporin A. 16 were blindly assigned to one of two $\mathrm{GH}$ doses (4 vs $8 \mathrm{IU}$ per $\mathrm{m}^{2}$ per day). Growth, bone maturation, renal graft function, plasma insulinlike growth factors, serum binding proteins, and other biochemical parameters were checked regularly. Glomerular filtration rate and effective renal plasma flow were tested with ${ }^{125}$-Thalamate and ${ }^{131}$-Hippuran. Data on growth and glomerular filtration rate during $\mathrm{GH}$ treatment were also compared with those of matched non-GH-treated controls. Mean (standard deviation) increment in height after 2 years of GH was $15.7(5.1) \mathrm{cm}$, significantly greater $(p<00001)$ than in matched controls, $58(34) \mathrm{cm}$. Results were similar for the two $\mathrm{GH}$ dosage groups. Bone maturation was not accelerated. Glomerular filtration rate and effective renal plasma flow did not change significantly. The incidence of a $>25 \%$ reduction in glomerular filtration rate over 2 years was not significantly higher in GH-treated patients than in non-GHtreated controls $(39 \%$ vs $32 \%, p=0.97)$. Although a few patients had deterioration of graft function, we could not find a relation with $\mathrm{GH}$ treatment.

Our results show that sustained improvement of height can be achieved with GH in severely growth-retarded adolescents after renal transplantation.

Lancet 1994; 343: 1313-17

Dlvision of Endocrinology (A C S Hokken-Koelega MD,

S M P F de Munck Keizer-Schrama MD, S LS Drop MD) and Division of Nephrology (E D Wolff MD), Department of Pedlatrics, Sophia Chlidren's Hospltal, PO Box 70029, 3000 LL Rotterdam, Netherlands; Department of Epidemiology and Blostatistics (T Stijnen PnD, M A J de Ridder), Erasmus University, Rotterdam; Dlvision of Nephrology, Department of Pedlatrlcs, Radboud University Hospital of NiJmegen (M C JW de Jong MD); Division of Nephrology, Department of Pediatrics, Wilhelmina Children's Hospital/University Hospital (R A Donckerwolcke MD); Divislon of Nephrology, Department of Pediatrics, Academic Medical Centre/ Unlversity of Amsterdam ( $\mathrm{W}$ Groothoff $\mathrm{MD}$ ), Netherlands; and Unlversity Chlldren's Hospital, Tübingen, Germany (W F Blum MD)

Correspondence to: Dr A C S Hokken-Koelega

\section{Introduction}

Adult height remains below the 3rd percentile for approximately $75 \%$ of patients undergoing renal transplantation (RTx) before the age of $15 \mathrm{yr} .{ }^{1}$ Much of the growth retardation occurs before $R T x$ and the rate of growth may improve after RTx, but this improvement is rarely sustained. ${ }^{2,3}$ Poor growth before $\mathrm{RTx}$ has a significant negative influence on adult height, but the loss of growth potential during puberty also seems important. ${ }^{4}$

Why growth retardation should persist after RTx is not known. Children with post-RTx growth retardation appeared to have significantly lower mean plasma growth hormone $(\mathrm{GH})$ concentrations during $24 \mathrm{~h}$ profile testing than healthy controls, regardless of pubertal stage. ${ }^{5}$ Plasma insulin-like growth factors (IGF-I and -II) were within the normal range, ${ }^{3,5}$ but serum IGF-binding protein-3 (IGFBP-3) were above normal in all growth-retarded RTx recipients. ${ }^{5}$ Growth retardation after $\mathrm{RTx}$ may be the result of inhibitory effects of prednisone treatment on $\mathrm{GH}$ secretion as well as to decreased IGF-bioavailability. Recent studies have shown that recombinant human growth hormone $(\mathrm{GH})$ treatment accelerates growth significantly in children with chronic renal insufficiency.$^{6,7}$ Preliminary reports of enhanced growth with $\mathrm{GH}$ treatment in renal allograft patients are promising ${ }^{8}$ but it has been suggested that GH might adversely effect graft function. ${ }^{9}$

We report a 2-year, double-blind, dose-response trial of GH in pubertal post-RTx patients with growth retardation compared with non-GH-treated matched controls, during which renal graft function was measured. The trial compared 4 IU GH per $\mathrm{m}^{2}$ per day with 8 IU GH per $\mathrm{m}^{2}$ per day in terms of growth, bone maturation, renal graft function, plasma IGF-I and IGF-II, serum IGFBP-1 and IGFBP-3, and other parameters.

\section{Patients and methods}

18 adolescent renal allograft recipients with growth retardation were enrolled; 10 boys and 8 girls, aged $11 \cdot 3-19 \cdot 5$ years with a mean (standard deviation) age of $15 \cdot 6(2 \cdot 3)$. Written informed consent was obtained from patients and their parents. The study was approved by the medical ethics committees of the participating centres. Inclusion criteria were: $\geqslant 12$ months after renal transplant; stable without rejection episodes for at least 6 months; growth retardation with a height standard deviation score (SDS) for chronological age $\left(\mathrm{hSDS}_{\mathrm{CA}}\right)$ below $-1 \cdot 88^{10}$ and a height velocity (HV) for chronological age below the 50th percentile ${ }^{11}$ or, conversely, a hSDS $\mathrm{CA}$ above -1.88 and a $\mathrm{HV}$ below the 25 th percentile; prednisone dosage $\leqslant 0.25 \mathrm{mg}$ per $\mathrm{kg}$ per day or $0.50 \mathrm{mg}$ per $\mathrm{kg}$ per alternate day for $\geqslant 6$ months; normal concentration of serum thyroid hormone and a normal acid-base balance; no history of sex-hormone treatment; and no evidence of a cause for growth retardation other than RTx. In two patients, a boy and a girl, respectively aged 14.1 and 13.0 years with bone ages of 13.9 and $13.0, \mathrm{hSDS}_{\mathrm{CA}}$ did fall below -1.88 , but theır HV was slightly 


\begin{tabular}{|c|c|c|}
\hline & Treatment regimen & \\
\hline & $\begin{array}{l}\text { Group } A \\
\text { GH } 4 \mathrm{IU} / \mathrm{m}^{2} \text { per day }(n=9)\end{array}$ & $\begin{array}{l}\text { Group } B \\
\text { GH } 8 \mathrm{IU} / \mathrm{m}^{2} \text { per day }(n=7)\end{array}$ \\
\hline Sex & 5 male, 4 female & 4 male, 3 female \\
\hline Age (yr) & $155(26)$ & $157(19)$ \\
\hline Bone age (yr) & $126(24)$ & $123(20)$ \\
\hline $\begin{array}{l}\text { Pubertal stage: } \\
\text { early } \\
\text { late }\end{array}$ & $\begin{array}{l}5 \\
4\end{array}$ & $\begin{array}{l}5 \\
2\end{array}$ \\
\hline $\begin{array}{l}\text { Prednisone regimen } \\
\text { alternate-day } \\
\text { daily }\end{array}$ & $\begin{array}{l}7 \\
2\end{array}$ & $\begin{array}{l}3 \\
4\end{array}$ \\
\hline
\end{tabular}

Table 1: Pretreatment clinical data for 16 dose-response study patients

above the 50th percentile due to the onset of pubertal growth spurt 6 months previously. Their growth data were not included in evaluation of the entire cohort, but were compared with appropriate matched controls.

Immunosuppression was by prednisone (for all but 1 patient), with either azathioprine (Aza) or cyclosporin A (CsA) or both. 10 patients received prednisone on alternate days $(\mathrm{AD})$ and 7 daily (D). To enable comparison, prednisone dosage was converted to a daily dose in all calculations, amounting to a similar median dose for $\mathrm{AD}$ and $\mathrm{D}$ patients of $0.15 \mathrm{mg}$ per $\mathrm{kg}$ per day, with a range of $0 \cdot 10-0 \cdot 25$. All but 1 patient had a cadaveric renal graft. 15 patients underwent plasma GH and cortisol profile testing, for 10 of them lasting $48 \mathrm{~h}$ and for 5,24h. The results of these tests are described elsewhere. ${ }^{5}$

At enrolment and subsequently every 3 months, all patients were examined by ACSH-K at participating centres. Height was measured with a Harpenden stadiometer at the same time of day and repeated until three consecutive readings were within $0 \cdot 2 \mathrm{~cm}$. Patients were always weighed on the same scales. Pubertal stage was determined according to Tanner, ${ }^{12}$ whereby early puberty was defined as Tanner stage $2 / 3$ with signs of early pubertal growth spurt and late puberty as Tanner $4 / 5$ with declining growth at the end of the growth spurt. Parental height served to calculate target height for each patient individually, with the exception of one adopted child. Secular trend was taken into account: father's + mother's height $+/-12 \mathrm{~cm} / 2,+3 \mathrm{~cm}$.

After stratification for pubertal stage, patients received one subcutaneous injection per day (at bedtime) of biosynthetic GH (Norditropin, Novo Nordisk A/S) in a dose of either 4 or $8 \mathrm{IU}$ per $\mathrm{m}^{2}$ body surface. 16 were randomly and blindly assigned to one or the other dosage in an equal volume of a reconstituted preparation, while the 2 patients who did not meet inclusion criterion were put on $4 \mathrm{IU} / \mathrm{m}^{2}$ per day. Bone age was determined by the same investigator according to Tanner-Whitehouse: ${ }^{12}$ radiographs of left hand and wrist were taken at the start of the study and subsequently every 6 months. Glomerular filtration rate (GFR ${ }^{125}$ I-Thalamate clearance test) and effective renal plasma flow (ERPF) ( ${ }^{131} \mathrm{I}$-Hippuran test) ${ }^{13}$ expressed as $\mathrm{mL} / \mathrm{min}$ per $1.73 \mathrm{~m}^{2}$ were measured at one participating centre (Sophia Children's) at the start of the study and after 2 and 12 months.

Blood and urine samples were taken at each examination for blood cell count, serum electrolytes, urea- $\mathrm{N}$, creatinine, calcium, phosphate, and alkaline phosphatase; and urine glucose, protein, blood, and sediment. Additional blood samples were taken at the start of the study and subsequently every 6 months for other analyses. After centrifugation, plasma samples were frozen $\left(-20^{\circ} \mathrm{C}\right)$ until assayed. Concentrations of plasma IGF-I and IGF-II were determined by a specific radioimmunoassay after acid chromatography. ${ }^{14}$ Methods used for quantifying IGF-binding protein-1 and -3 (IGFB-1 and -3 ) are described elsewhere. ${ }^{15}$ Concentrations of IGFs and IGF-binding proteins were transformed to SDS for bone age $\left(\mathrm{SDS}_{\mathrm{BA}}\right)$. Concentrations of plasma parathyroid hormone were measured with a two-step immunochemical method. ${ }^{16}$
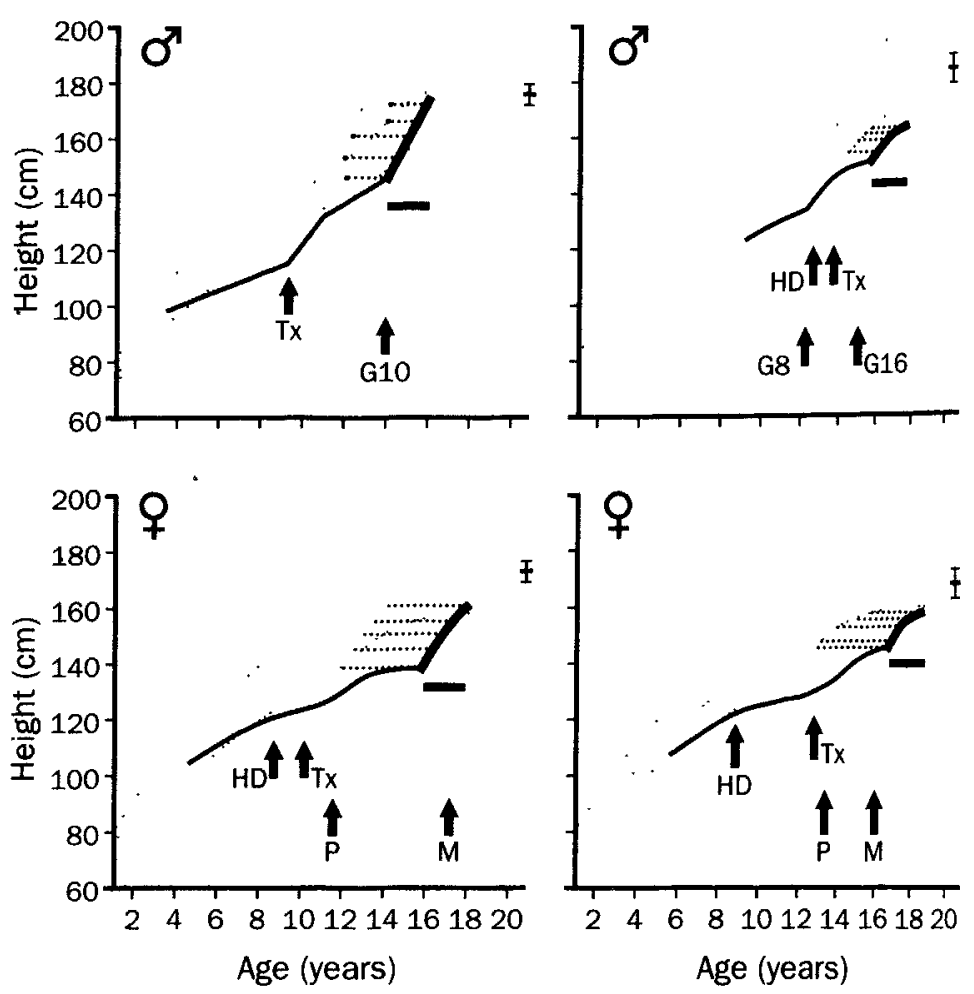

Figure: Growthcharts of 4 pubertal renal allograft reciplents who recelved GH

Dashed lines $=$ bone age, black bar = period of growth hormone therapy, $\mathrm{HD}=$ start of haemodialysis, $\mathrm{Tx}=$ renal transplantation, $\mathrm{I}=$ target height $+/-4 \mathrm{~cm}, \mathrm{P}=$ \%, start of puberty (Tanner stage M2), $\mathrm{M}=$ menarche, $\mathrm{G}=\delta$ testicular volume in $\mathrm{mL}$.

Height was expressed as SDS for chronological age (hSDS $\mathrm{CA}_{\text {), }}$ ie, compared with Dutch reference data ${ }^{10}$ and in $\mathrm{cm}$. We did a multiple regression analysis with the 1-year increment in height (cm) in order to evaluate the influence of various variables on height gain during $\mathrm{GH}$ treatment. In addition, we compared the 1-year and 2-year height increment of our GH-treated patients to that of a matched control group. For each GH-treated patient, controls were selected who would have been included in our GH trial if this had been conducted at that time. They were selected from a group of 149 patients who had their first RTx before the age of 15 during the last decade and who had never received $\mathrm{GH}^{1}$ and matched on sex, chronological age, pubertal stage, time elapsed from $\mathrm{RTx}$, immunosuppressive drug regimen, and retrospective fulfillment of all inclusion criteria of the GH trial. The two additional patients were compared with matched controls whose prestudy HV had likewise been above the 50th percentile for 6 months.

In addition to GFR and ERPF determination during the first year of the trial, we also determined the GFR for each year of the study separately, by a height/plasma formula. ${ }^{17}$ As there was no significant difference between the mean calculated GFR and the mean measured GFR during the first study in the GH-treated patients, we compared their calculated results with those of controls. The GFR at the start of the study period was divided into 3 strata: $>70 \mathrm{~mL} / \mathrm{min}$ per $1.73 \mathrm{~m}^{2} ; 40-70 \mathrm{~mL} / \mathrm{min}$ per $1.73 \mathrm{~m}^{2}$; and $<40 \mathrm{~mL} / \mathrm{min}$ per $1.73 \mathrm{~m}^{2}$.

Deterioration of renal graft function was considered to be substantial when GFR was reduced by $>25 \%$ during the study period. When a patient returned to dialysis or received another RTx, the GFR was considered to be $<10 \mathrm{~mL} / \mathrm{min}$ per $1.73 \mathrm{~m}^{2}$ for the rest of the study. Statistical analysis was by TS who alone knew the code of the assignment to dosage group to this day. The double-blind, dose-response design of the study will continue until all patients have reached final height, unless safety problems appear in relation to either GH dosage. Paired $t$-test was used for differences within each dosage group, and the Student two-sample $t$-test for differences between groups. Comparison of the incidence of a GFR reduction $>25 \%$ during the study period between GH-treated patients and non-GH-treated controls was done by conditional logistic regression analysis. 


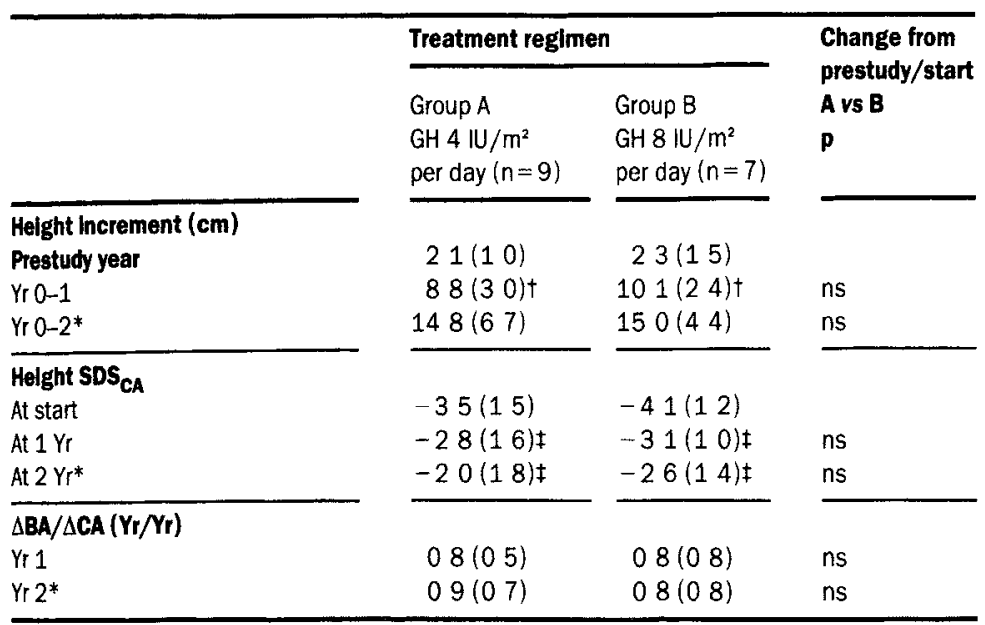

$\mathrm{hSDS}_{\mathrm{CA}}=$ height standard deviation score for chronologıcal age; $\mathrm{BA}=$ bone age;

$C A=$ chronological age; *Group $A(n=7)$; Group $B(n=5) ; t p<0001$ compared with prestudy year; $\ddagger p<005$ compared with prestudy year. $n s=$ not significant.

Table 2: Mean (SD) height increment, height SDS $_{\mathrm{CA}}$ and advance in bone maturation ( $\triangle \mathrm{BA} / \triangle \mathrm{CA}$ )

\section{Results}

Table 1 shows comparable pretreatment data for the 16 dose-response study patients. 3 patients did not complete the 2-year study period: 2 resumed dialysis (after 15 and 16 months, respectively) while the third was a late entrant to the study, completing a follow-up of 18 months.

Individual growth charts of 4 patients are shown in the figure. Due to the double-blinded design and ongoing nature of the study, GH doses are not shown. Table 2 shows the effect of 2 different doses of $\mathrm{GH}$ on the height increment and $h S D S_{C A}$, and bone maturation in all patients. Mean height increment was significantly greater during both the first and second year of the GH study $(p<0.001$ and $<0.05$, respectively). Similarly, there was a significant increase in mean $\mathrm{hSDS}_{\mathrm{CA}}$ after two years of $\mathrm{GH}(\mathrm{p}<0.01)$. However, there was no significant difference for any of these growth parameters between the patients who received 4 IU and 8 IU GH per $\mathrm{m}^{2}$ per day. The mean (SD) height increment during 2 years of $\mathrm{GH}$ therapy was $14.8(6 \cdot 7) \mathrm{cm}$ in group A and $15.0(4.4) \mathrm{cm}$ in group B. Bone maturation was not accelerated by $\mathrm{GH}$ treatment and was similar for both groups.

To evaluate the influence of variables on height gain during $\mathrm{GH}$ treatment, we did a multiple regression analysis with the 1-year increment in height $(\mathrm{cm})$ as the dependent variable. Independent variables were: $\mathrm{GH}$ dose, pubertal stage, prestudy HV $(\mathrm{cm})$, and prednisone dose. Early puberty (Tanner stage 2/3) was associated with a significantly higher increment in height $(p=0.0001)$, the difference with late puberty being $4.6 \mathrm{~cm}$, provided the other factors are equal. The higher $\mathrm{GH}$ dose was associated with a slightly higher increment in 1-year height of $0.6 \mathrm{~cm}$, which was not significant $(95 \%$ confidence interval, $-1 \cdot 3$ to $2.5 \mathrm{~cm}$ ). Nor did prestudy HV or alternate-day $v s$ daily prednisone have a significant influence on the increment in height during 1 year of $\mathrm{GH}$.

$16 \mathrm{GH}$-treated patients had from 2 to 4 (mean 3 ) matched controls each for comparison of height increment over 1 year, while 14 had matched controls over 2 years. The mean (SD) increment in height in GH-treated patients was significantly higher than in matched controls: $10 \cdot 0(2 \cdot 3) \mathrm{vs}$ $3.4(1.7) \mathrm{cm}$ over 1 year $(\mathrm{p}<0.0001)$ and $15 \cdot 7(5 \cdot 1)$ ws 5.8 $(3.4) \mathrm{cm}$ over 2 years $(\mathrm{p}<0.0001)$.

Two girls had one episode of acute rejection confirmed by biopsy, respectively 7 and 15 months after the start of $\mathrm{GH}, 19$ and 60 months after the first RTx. For one, the dose of prednisone and cyclosporin had been reduced during the weeks before the event. They responded well to antirejection treatment and continued GH. Two boys had deterioration of renal function, respectively 11 and 12 months after starting $\mathrm{GH}, 30$ and 40 months after their second RTx. One of them had not complied with immunosuppressive drugs, the other had hepatitis- $C$ and herpes infection, and his daily dose of azathioprine was less than $1 \mathrm{mg} / \mathrm{kg}$. This patient stopped $\mathrm{GH}$ when repeated anti-rejection courses did not succeed, but the decline in GFR continued as before. Both patients resumed dialysis. Another boy ( 36 months after the first RTx) had a constant GFR until he stopped taking immunosuppressive drugs for almost 2 months (from 13-15 months after start of GH), which resulted in a $>25 \%$ decline in GFR despite antirejection treatment. GH was continued and GFR stabilised.

GFR and ERPF were measured in 14 dose-response study patients ( 8 group A, 6 group B). Two boys were not tested after 12 months because of end-stage renal failure (see above). For that reason, their GFR was set at 10 $\mathrm{mL} / \mathrm{min}$ per $1.73 \mathrm{~m}^{2}$ for analysis. There was no significant decline in mean GFR over 1 year of $\mathrm{GH}$ in either group. Mean (SD) GFR for group A at the start, at 2, and at 12 months of GH was: $66(12), 72(15), 64(25)$; and for group B: $67(18), 76(15), 60(33) \mathrm{mL} / \mathrm{min}$ per $1.73 \mathrm{~m}^{2}$. Likewise, there was no significant change in ERPF during 1 year in either dosage group. The mean (SD) ERPF for group A at the start, at 2 , and at 12 months was: 304 (70), 301 (80), 311 (82); and for group B: $268(73), 284(70), 260(86) \mathrm{mL} / \mathrm{min}$ per $1.73 \mathrm{~m}^{2}$.

7 of $18 \mathrm{GH}$ patients ( $39 \%$ ) had a $>25 \%$ decline in GFR during 2 years of $\mathrm{GH}$ treatment compared with 29 out of 90 controls $(32 \%)$. There was therefore no significant difference in the incidence of renal-graft deterioration between GH-treated and non-GH-treated patients $(\mathrm{p}=0.97)$. Evaluation of factors possibly associated with the $>25 \%$ decline in graft function showed no difference between a GH dose of 4 or $8 \mathrm{IU}$ per $\mathrm{m}^{2}$ per day (Fisher exact test, $p=1 \cdot 00$ ). However, we found a trend towards a negative influence of alternate-day prednisone on renal function during $\mathrm{GH}$ therapy (Fisher exact test, $\mathrm{p}=0 \cdot 15$ ): only 1 of 7 patients on daily prednisone had a $>25 \%$ decline in graft function in contrast to 6 of 11 patients who received alternate-day prednisone.

The mean (SD) pre-treatment IGF-I concentration expressed as SDS for bone age $\left(\mathrm{SDS}_{\mathrm{BA}}\right)$ was within normal for groups $\mathrm{A}$ and $\mathrm{B},(0 \cdot 1[1 \cdot 0]$ and $0.5[1 \cdot 4]$, respectively) (table 3). This concentration increased significantly during the first year of $\mathrm{GH}(\mathrm{p}<0.0001)$ in both groups and continued to increase significantly during the second year $(p<0.0001)$ (data not shown). There was no statistical difference in the $\mathrm{GH}$-induced increment in IGF-I between the groups. No correlation was found between either the IGF-I SDS $S_{\mathrm{BA}}$ at the start or its change and the change in height SDS for chronological age during 1 year of $\mathrm{GH}$. The mean (SD) plasma IGF-II concentration, expressed as $\mathrm{SDS}_{\mathrm{BA}}$, at the start of the study was within the normal range for groups $A$ and $B$, amounting to $0.7(1.0)$ and 0.7 $(0 \cdot 8)$, respectively. $\mathrm{GH}$ induced a similar significant decrease in the IGF-II SDS $_{\mathrm{BA}}$ in both groups $(\mathrm{p}<0.01)$ (table 3).

The serum concentration of IGFBP-3 was raised at the start of the study in both groups (mean [SD] $\mathrm{SDS}_{\mathrm{BA}}=3 \cdot 0$ [1.2] and $3.2[1.3]$, respectively) and this increased significantly during $\mathrm{GH}$ treatment in group $\mathrm{A}$ and $\mathrm{B}$ $(p<0.0001)$. Prestudy IGFBP-1 concentrations were raised 


\begin{tabular}{|c|c|c|c|c|}
\hline & \multicolumn{4}{|c|}{ Treatment reglmen } \\
\hline & \multicolumn{2}{|c|}{$\begin{array}{l}\text { Group A } \\
\text { GH } 4 I U / m^{2} \text { per day }(n=9)\end{array}$} & \multicolumn{2}{|c|}{$\begin{array}{l}\text { Group B } \\
\text { GH } 8 \mathrm{IU} / \mathrm{m}^{2} \text { per day }(n=7)\end{array}$} \\
\hline & Start & 1 year & Start & 1 year \\
\hline $\begin{array}{l}\text { IGF-I } \\
\mathrm{ng} / \mathrm{mL} \\
\mathrm{SDS}_{\mathrm{BA}}\end{array}$ & $\begin{array}{l}279(102) \\
01(10)\end{array}$ & $\begin{array}{l}529(136)^{*} \\
29(20)^{*}\end{array}$ & $\begin{array}{l}316(70) \\
05(14)\end{array}$ & $\begin{array}{l}576(11)^{*} \\
\quad 24(11)^{*}\end{array}$ \\
\hline $\begin{array}{l}\text { IGF-\| } \\
\mathrm{ng} / \mathrm{mL} \\
\mathrm{SDS} S_{\mathrm{BA}} \\
\end{array}$ & $\begin{array}{l}837(136) \\
07(10)\end{array}$ & $\begin{array}{l}694(213) \dagger \\
-02(13) \dagger\end{array}$ & $\begin{array}{l}816(109) \\
07(08)\end{array}$ & $\begin{array}{l}694(166) \dagger \\
-02(11) \dagger\end{array}$ \\
\hline $\begin{array}{l}\text { IGFBP-1 } \\
\mathrm{ng} / \mathrm{mL} \\
\mathrm{SDS}_{\mathrm{BA}} \\
\end{array}$ & $\begin{array}{l}38(13) \\
20(24)\end{array}$ & $\begin{aligned} & 24(12) \\
& 12(19)\end{aligned}$ & $\begin{array}{l}32(15) \\
24(22)\end{array}$ & $\begin{array}{l}40(29) \\
37(43)\end{array}$ \\
\hline $\begin{array}{l}\text { IGFBP-3 } \\
\mathrm{ng} / \mathrm{mL} \\
\mathrm{SDS}_{\mathrm{BA}}\end{array}$ & $\begin{array}{r}6404(1743) \\
30(12)\end{array}$ & $\begin{array}{r}9627(2193)^{*} \\
48(14)^{*}\end{array}$ & $\begin{array}{r}6964(2274) \\
32(13)\end{array}$ & $\begin{array}{r}9137(1730)^{*} \\
43(09)^{*}\end{array}$ \\
\hline
\end{tabular}

IGF = insulin-like growth factors. IGFBP = IGF-bındıng protein; $\mathrm{SDS}_{\mathrm{BA}}=$ standard deviation score for bone age; ${ }^{*}=p<00001$ compared to start of study; $t=p<001$ compared to start of study.

Table 3: Mean (SD) plasma concentrations of IGF and IGFbinding proteins

in both groups (mean $\operatorname{SDS}_{\mathrm{BA}}=2 \cdot 9[2 \cdot 4]$ and $2 \cdot 4[2 \cdot 2]$, respectively) and did not change significantly during $\mathrm{GH}$ treatment (table 3). There was a significant negative correlation between GFR at the start and serum IGFBP-1 $\operatorname{SDS}_{\mathrm{BA}} \quad(\mathrm{r}=-0.65 ; \mathrm{p}<0.01)$ and IGFBP-3 $\mathrm{SDS}_{\mathrm{BA}}$ $(\mathrm{r}=-0.46 ; \mathrm{p}=0.03)$. No correlation was found between pre-treatment concentrations of IGFBP-1 or IGFBP-3 and the change in $\mathrm{hSDS}_{\mathrm{CA}}$ before or during the study; nor did changes in IGF-binding proteins correlate with the growth response or the GFR during GH therapy. The effect of $1 \mathrm{yr}$ of $\mathrm{GH}$ was substantially greater on the increment of IGF-I than on the increment of IGFBP-3 (delta $\mathrm{SDS}_{\mathrm{BA}}=+2 \cdot 3$ vs $+1 \cdot 4$, respectively). Comparable results were found for the 9 patients whose GFR remained above $50 \mathrm{~mL} / \mathrm{min}$ per 1.73 $\mathrm{m}^{2}$ over 2 yr of $\mathrm{GH}$ treatment $\left(\mathrm{SDS}_{\mathrm{BA}}=+2 \cdot 8 v s+1.7\right.$, respectively).

Thyroid function was normal for all patients at the start and remained so during the study. Mean (SD) serum alkaline phosphatase increased significantly during the first 6 months of $\mathrm{GH}$ from 209 (83) to 264 (91) $\mathrm{mMol} / \mathrm{L}$ $(p=0 \cdot 03)$, without a significant difference between group $A$ and $B$. There was no significant change in the parathyroid hormone concentrations during $\mathrm{GH}$ regardless of dosage.

\section{Discussion}

This study shows that biosynthetic $\mathrm{GH}$ gives an impressive increment in height and height SDS $_{\mathrm{CA}}$ in adolescents with growth retardation after $\mathrm{RTx}$ at 4 or $8 \mathrm{GH} \mathrm{IU} / \mathrm{m}^{2}$ per day. These results contrast with reports that $\mathrm{GH}$ after renal transplant is less effective in pubertal than in prepubertal children. ${ }^{18}$ The GH-induced increment in height was significantly higher in the children at an early pubertal stage compared with those at a late pubertal stage. However, even patients who were nearing completion of puberty had a marked increase in height.

Effects of $\mathrm{GH}$ are more difficult to evaluate during puberty. A placebo-controlled study would only provide valuable data if patients were matched and paired before the start of the study on the basis of several variables, including pubertal stage, which is unlikely to be feasible. As an alternative, we compared 2-year height increment of our $\mathrm{GH}$-treated patient group with that of a non-GH treated patient group who were matched retrospectively. In accordance with the above findings, the 2-year growth of our GH-treated patients proved to be significantly greater than that of the matched controls. During 2 years of $\mathrm{GH}$ treatment, bone maturation did not accelerate with either dose; on the contrary, bone age in some patients advanced less than expected. Our results indicate that GH may well improve final height of pubertal patients with short stature after RTx, even in patients with advanced pubertal stage.

One major concern of $\mathrm{GH}$ treatment is its possible action on renal graft function, either the risk of acute rejection crises or progressive deterioration of function. If $\mathrm{GH}$ reverses the catabolic effects of prednisone, ${ }^{19}$ it might also modulate its immunosuppressive effects, whereas permanent hyperfiltration might produce glomerular sclerosis and thereby accelerate progression of renal graft destruction. $^{20}$ During 2 years of $\mathrm{GH}$, only 2 out of 18 patients had one episode of biopsy-proven acute rejection, a number no different from that occurring in the non-GHtreated control group. Although 3 patients had progressive graft deterioration during $\mathrm{GH}$ treatment, a direct relation with $\mathrm{GH}$ seems unlikely since there were other reasons for deterioration.

We measured the effect of GH on GFR and ERPF by accurate methods. It appeared that 1 year of GH did not result in a change in mean GFR. In addition, no significant change in mean ERPF occurred. Many patients showed a gradual increase in serum creatinine during the first 6 months of GH not associated with rejection, and GFR showed stable graft function in most patients. GH reportedly increases muscle mass whilst reversing prednisone-induced catabolism; ${ }^{19}$ increased serum creatinine probably reflects increased muscle mass due to GH. The number of GH-treated patients with $>25 \%$ decline in GFR was not significantly different from the number found in non-GH-treated matching controls. As our control group was matched for immunosuppressive treatment, changes in drug regimens can not have influenced the results.

The most striking finding was that 6 of 11 patients $(55 \%)$ receiving alternate-day prednisone during $\mathrm{GH}$ therapy had a $>25 \%$ decline in renal function in contrast with only 1 out of 7 patients $(14 \%)$ on daily prednisone. Several studies in non-GH treated patients have reported that alternate-day prednisone had reduced growth-depressing effects, ${ }^{21}$ although most investigators concluded this regimen was not associated with increased risk of rejection. ${ }^{22}$ Only one author reported a higher incidence of rejection in non- $\mathrm{GH}$ treated patients on alternate-day prednisone. ${ }^{23}$ It may be that GH stimulates the immune system on the prednisonefree day, thus precipitating progressive graft deterioration.

Pretreatment plasma IGF-I concentrations were normal for patients receiving either $\mathrm{GH}$ dose, in agreement with findings in other RTx patients. ${ }^{3}$ Pretreatment concentrations of serum IGF-binding protein-3 (IGFBP3) were significantly increased, resembling the findings in growth-retarded children with chronic renal insufficiency (CRI) ${ }^{6} \mathrm{GH}$ treatment induced a significant increase in serum concentrations of GH-dependent IGF-I and to a lesser degree IGFBP-3. Pretreatment plasma concentration of IGF-II were normal and GH induced a significant decrease in mean levels, regardless of dosage. Pretreatment serum IGFBP-1 concentrations were raised in all patients, but not to the degree that we found in growth-retarded children with CRI. ${ }^{5}$ In CRI patients, GH induced a significant decrease in serum IGFBP-1 concentrations, but did not change significantly during $\mathrm{GH}$ treatment in the post-RTx patients. Before the start of $\mathrm{GH}$ there was a significant inverse correlation between the IGFBP-3, IGFBP-1, and graft GFR which disappeared 
with GH. Excess of serum IGFBP-3 causes a decrease in IGF-bioactivity. ${ }^{24}$ In addition, in-vivo IGF bioassays show an inhibitory effect of the small-molecular-weight IGFBP1 on IGF-stimulated biogenesis and cell metabolism. ${ }^{25}$ Thus, it may be that reduced graft function together with raised concentrations of IGFBP's and decreased IGFbioavailability are involved in growth retardation after RTx.

Prednisone treatment is believed to be mainly responsible for growth retardation after $\mathrm{RTx}$. Alternateday prednisone was found to reduce but not eliminate growth retardation. ${ }^{26}$ Prednisone-induced inhibition of local IGF-I gene expression and inhibition of GH secretion might be mechanisms of growth retardation. ${ }^{27-29}$ Significantly improved growth during GH may have been due to the positive effect of GH on IGF-I and improved bioavailability coupled with the direct growth-promoting effect on target tissues, ${ }^{30}$ thus confirming animal studies which show that the growth-depressing effects of corticosteroids can be overcome by GH. ${ }^{19}$ Serum alkaline phosphatase concentration increased significantly during the first 12 months of $\mathrm{GH}$, but there was no radiological signs of renal osteodystrophy, so the increase may be due to osteoblastic activity resulting from $\mathrm{GH}$.

2 years of $\mathrm{GH}$ in a dose of either 4 or $8 \mathrm{IU}$ per $\mathrm{m}^{2}$ per day results in a significant and sustained improvement of height in pubertal patients with growth retardation after RTx. As there was no acceleration in bone maturation, $\mathrm{GH}$ may well improve the final height of these patients. Although a small number of patients had progressive deterioration of graft function, we could not find a relation with $\mathrm{GH}$ treatment. In view of the difference in graft deterioration observed between patients on alternate-day and those on daily prednisone therapy, it seems worthwhile to investigate the optimal prednisone regimen for the duration of $\mathrm{GH}$ therapy.

We thank Mrs E van Brakel and Mrs A Saarloos for their assistance with the physical examinations, Mrs J Drost-van der Linden for secretarial assistance, and Mrs A Ribbink-Goslinga for editing the manuscript. This study was supported by a grant from Novo Nordisk A/S, Denmark.

\section{References}

1 Hokken-Koelega ACS, Van Zaal MAE, Van Bergen W, et al. Final height and its predictive factors after renal transplantation in childhood. Pediatr Res 1994 (in press)

2 Rizzoni $G$, Basso T, Setari $M$. Growth in children with chronic renal failure on conservative treatment. Kidney Int 1984; 26: 52-58.

3 Rees L, Greene SA, Adlard P, et al. Growth and endocrine function after renal transplantation. Arch Dis Child 1988; 63: 1326-32.

4 Van Diemen-Steenvoorde $\mathrm{R}$, Donckerwolcke RA, Brackel $\mathrm{H}_{\text {, }}$ Wolff ED, De Jong MCJW. Growth and sexual maturation in children after kidney transplantation. $\mathcal{F}$ Pediatr 1987; 110: 351-56.

5 Hokken-Koelega ACS, Stijnen T, De Muinck Keizer-Schrama SMPF, Blum WF, Drop SLS. Levels of growth hormone, IGF-I and -II, IGFBP-1 and -3, and cortisol in prednisone treated children with growth retardation after renal transplantation. $\mathcal{J}$ Clin Endocrinol Metab 1993; 11: 932-39.

6 Hokken-Koelega ACS, Stijnen T, De Muinck-Keizer-Schrama SMPF, et al. Placebo-controlled, double-blind cross-over trial of growth hormone treatment in prepubertal children with chronic renal failure. Lancet 1991; 338: 585-90.

7 Tonshoff B, Mehls O, Heinrich U, Blum WF, Ranke M, Schauer A. Growth stimulating effects of recombinant growth hormone in children with end-stage renal disease. F Pedıatr 1990; 116: 561-66.
8 Fine RN, Yadin O, Nelson PA. Recombinant human growth hormone treatment of children following renal transplantation. Pediatr Nephrol 1991; 5: 147-51.

9 Watson AR. Safety of growth hormone. Lancet 1991; 337: 108.

10 Roede MJ, Van Wieringen JC. Growth diagrams 1980. Netherlands third nation-wide biometric survey. Tijdschr Soc Gezondheidszorg 1985; 63: 1-34.

11 Tanner JM, Whitehouse RH. Longitudinal standards for height, weight, height, weight-velocity and stages of puberty. Arch Dis Chuld 1976; 51: 170-79.

12 Tanner JM, Whitehouse RH, Cameron N, Marshall WA, Healy MJR, Goldstein $\mathrm{H}$. Assessment of skeletal maturity and prediction of adult height (TW2 method), 2nd ed. London: Academic Press, 1983.

13 Zietse R, Derkx FHM, Pos B, Blankenstijn PJ, Balk AAM, Schalekamp MADH. Optimalization of thalamate and hippurate clearance measurements in patients with severe impaired renal function by adjustment of the infusion rate according to prior estimation of GFR and ERPF with the cockroft formula. Kidney Int 1993; 43: 969.

14 Hokken-Koelega ACS, Hackeng WHL, Stijnen T, Wit JM, De Muinck Keizer-Schrama SMPF, Drop SLS. 24-hour plasma GH profiles, urinary GH excretion and plasma IGF-I and -II levels in prepubertal children with chronic renal insufficiency and severe growth retardation. F Clin Endocrinol Metab 1990; 71: 688-95.

15 Blum WF, Ranke M, Kietzmann K, Tönshoff B, Mehls O. Excess of IGF-binding protein in chronic renal failure: evidence for relative $\mathrm{GH}$ resistance and inhibition of somatomedin activity, in Proceedings of the workshop on IGF binding proteins. Drop SLS, Hintz RL, eds. Vancouver, Canada, Amsterdam: Elsevier, 1989.

16 Hackeng WHL, Lips P, Netelenbos JCM. Clinical implications of estimation of intact parathyroid (PTH) versus total immunoreactive PTH in normal subjects and hyperparathyroid patients. $\mathcal{f}$ Clin Endocrinol Metab 1986; 63: 447-53.

17 Morris MC, Allanby CW, Toseland P. Evaluation of a height/ plasmacreatinine formula in the measurement of glomerular filtration rate. Arch Dis Child 1982; 57: 611-14.

18 Ingulli E, Singh A, Moazami S, Tejani A. Prednisone inhibits the efficacy of recombinant human growth hormone in pediatric renal transplant recipients. Kid Int 1993; 44: 65-70.

19 Kovacs G, Fine RN, Worgall S, et al. Growth hormone prevents steroid-induced growth depression in health and uremia. Kidney Int 1991; 40: 1032-40.

20 Doi T, Striker LJ, Quaife C. Progressive glomerulosclerosis develops in transgenic mice chronically expressing growth hormone and growth hormone releasing factor but not in those expressing insulin-like growth factor-1. Am F Pathol 1988; 131: 398-403.

21 Polito C, Oporto MR, Totino SF, La Manna A, Di Toro R. Normal growth of nephrotic children during long-term alternate-day prednisone therapy. Acta Paediat Scand 1986; 75: 245-50,

22 Broyer M, Guest G, Gagnadoux MF. Growth rate in children receiving alternate-day corticosteroid treatment after kidney transplantation. $\mathcal{F}$ Pediatr 1992; 120: 721-25.

23 Leb DE. Alternate-day prednisone treatment may increase kidney transplant rejections. Proc Dial Transpl Forum 1979; 9: 136-41.

24 Blum WF, Ranke MB, Kietzmann K, Tonshoff B, Mehls O. Growth hormone resistance and inhibition as somatostatin activity by excess of insulin-like growth factor binding protein in uremia. Pediatr Nephrol 1991; 5: 539-44.

25 Schuller AGP, Lindenbergh-Kortleve DJ, de Boer WL, Zwarthoff EC, Drop SLS. Localisation of the epitope of a monoclonal antibody against human IGFBP-1, functionally interfering with IGF binding. Growth Regulation 1993; 3: 32-34.

26 Bosque M, Munian A, Bewick M, Haycock G, Chantler C. Growth after renal transplants. Arch Dis Child 1983; 58: 110-14.

27 Allen DB, Goldberg BD. Stimulation of collagen synthesis and linear growth by growth hormone in glucocorticoid-treated children. Pediatr 1992; 89: 416-21.

28 Nagakawa $K$, Ishizuka $T$, Obara $T$, Matsubara $M$, Akikawa $K$. Dichotomic action of glucocorticoids on growth hormone secretion. Acta Endocrinol (Copenh) 1987; 116: 165-71.

29 Wehrenberg WB, Janowski BA, Piedrıng AW, Cullier F, Jones KL. Glucocorticoids: Potent inhibitors and stimulators of growth hormone secretion. Endocrinology 1990; 126: 3200-03.

30 Isaksson OGP, Jansson JO, Gause IDM. Growth hormone stimulates long bone growth directly. Science 1982; 216: 1237-39. 